\title{
DOPPLER VELOCIMETRY OF THE UTERINE ARTERIES: AN EARLY SCREENING TEST FOR MISCARRIAGE
}

\author{
Ilian Trayanov, Elena Dimitrakova
}

UMBAL St. George - Plovdiv, Department of Obstetrics and Gynecology

Chair of Obstetrics and Gynecology, Plovdiv, R. Bugaria

Corresponding Author: UMBAL St. George - Plovdiv, Department of Obstetrics and Gynecology Chair of Obstetrics and Gynecology GSM 0898233776; E-mail: lilianski2000@yahoo.co.uk

\begin{abstract}
Introduction: According to the WHO, miscarriage is defined as "the loss of a pregnancy before the age of 20 weeks of gestation or fetal weight below $500 \mathrm{~g}$ ". Only 50-60\% of all conceptions fail to survive 20 weeks of gestation. It is estimated that about $75 \%$ of all unsuccessful conceptions are due to failed implantation and are not reported as spontaneous abortions.

Material and Methods: We performed a prospective observational study at the Department of Obstetrics and Gynecology of the Medical University Plovdiv between October 2014 and September 2015. We studied two groups of pregnant women: women with threatened abortion and those with normal pregnancy. All women underwent a transvaginal ultrasound evaluation of the uterine arterial blood flow. We measured peak systolic and end-diastolic velocity and calculated the average IR (resistance index) and S / D (systolic to diastolic ratio).

Results: There was no association between pregnancy outcome and the mean difference between uterine arterial IR and S / $(\mathrm{P}>0.05)$.

Conclusion: In our study, Doppler ultrasound could not differentiate between women at risk for miscarriage and normal women. Further studies are necessary to answer this question.
\end{abstract}

Keywords: Doppler ultrasound, index of resistance, pregnancy, threatened abortion

\section{Introduction}

According to the World Health Organization (WHO), "miscarriage is the loss of a pregnancy before 20 weeks of gestation or fetal weight below $500 \mathrm{~g}$ " [1]. Only $50-60 \%$ of all conceived embryos fail to exceed 20 weeks gestation. It is estimated that about $75 \%$ of all unsuccessful conceived pregnancies are due to failed implantation and are not reported as "spontaneous abortion" [2]. Despite the constant progressive growth of the embryo and the trophoblastic tissue, the anatomy of the pelvis does not change dramatically in the first trimester after implantation. During this period, the main changes are reflected in the uterine blood flow. Uterine perfusion increases during pregnancy starting from the first quarter and this change can be documented using Doppler ultrasound [3].

Many congenital and acquired changes in the vascular wall of the endometrial spiral arteries can lead to inadequate fetal implantation of the fertilized oocyte. Spiral artery blood flow is affected by endothelial factors which change the velocity of the blood flow and can predispose to thrombosis [4].

Normal implantation and placentation are very important for the successful outcome of pregnancy. Suboptimal implantation and placentation can lead to miscarriage or complications in late pregnancy, such as preterm delivery or preeclampsia [5]. Placentation provides uteroplacental circulation and allows the tro- 
phoblast to come in direct contact with maternal blood. A multitude of cellular and molecular signals affect implantation. Blastocyst invasion involves sex steroids, peptide hormones, growth factors, cytokines and immunological factors [6-8]. Excessive invasion resulting from improper countering the invasion of blastocyst by maternal tissues leads to placenta accreta or percreta. Inadequate invasion can result in miscarriage, preeclampsia or premature birth. Although the regulatory mechanisms are not fully understood, there is an urgent need to develop and validate tests that can identify pregnancies that are at high risk for miscarriage or complications [5].

Objective: To determine the prognostic value of Doppler ultrasound of the uterine arteries in patients diagnosed with threatened abortion.

\section{Materials and methods}

We performed a prospective observational study in the Department of Obstetrics and Gynecology at the UM Plovdiv for the period October 2014 - September 2015. We excluded pregnant women with subchorionic hematoma, slow heart rate of the fetal, abnormal yolk sac (missing, with a solid ultra-sonographic density, abnormal size, duplicate), less-than-gestational-age fetus, lack of heartbeat, multiple pregnancy, ectopic pregnancy, structural changes in cervical comorbidities that increase the risk of miscarriage (thrombophilia, anti-phospholipid syndrome), or parents with genetic diseases.

98 pregnant women (mean age, 26.54) were included in the study. The women were presented to the "DKC-6 Central Region Plovdiv" outpatient department or were inpatients at the "St. George's Multiprofile Hospital for Active Treatment". 27 did not meet inclusion criteria and were excluded. The remaining 71 pregnant women were divided into two groups. 35 patients were diagnosed with threatened abortion (group 1) and 36 women had normal pregnancies (group 2).

After explaining the method and completing the informed consent form, the women underwent ultrasound transvaginal examination. In order to measure blood flow of the uterine arteries we used GE Voluson E6, Voluson 730 and Philips ClearVue 650 equipment.
For the research we used color and pulsed Doppler velocity. After visualization of the left and right uterine artery at the level of corpocervical junction, in real time under the minimum angle (if necessary, the angle can be manually adjusted) the Doppler beam is directed to the blood vessel. There was a recording from 3 to 6 wave curves of uniform shape and a quality (filters between 50 and 100 hertz were used to help) performance of the measurement. After registering the peak systolic and end diastolic frequency with computer program we recognized the average value of the IR (index of resistance) and S / D (the ratio systole and diastole).

Based on the purpose, the objectives of the survey, the volume and type of data we used the following statistical methods:

We applied descriptive statistics to describe the results. The results are presented by arithmetic mean, standard deviation and standard error (mean, Std. Deviation and Std. Error).

We made an evaluation of the percentage and the frequency allocations in qualitative data and we grouped the data performed by an alternative analysis.

For comparison of the results in more than two independent samples analysis of variance (ANOVA) and the Kruskal Wallis Test were used.

For comparison of two independent samples we used criteria and the Mann-Whitney U test. For comparisons of the results in two-dimensional distributions we applied the criterion $\chi^{2}$.

In order to search for a relationship between variables - Pearson and Spearman's rho;

In order to illustrate the addictions we used the capabilities of the graphical analysis.

The level of significance of the null hypothesis was accepted at $\mathrm{P}<0.05$. The data were processed by statistical software package SPSS ver.16.0.

\section{Results}

We studied 71 pregnant women divided into two groups. Thirty-six women were diagnosed with threatened abortion and thirty-five women had a normal pregnancy. The threa- 
tened abortion group had an average age of 27.03, the healthy group age was 26.04 years. We did not find a significant difference between the two groups by age $\mathrm{P}>0,05(\mathrm{t}=0.44)$ (Table 1 and Table 2). We did not find an association between the pregnancy outcome and the values of the difference between IR and S / D of the left and right uterine artery $\mathrm{P}>0.05$ (Table 3).
Table 1

Mean age of patients in the two examined groups

\begin{tabular}{|c|c|c|c|c|}
\hline Groups & N & Mean & $\begin{array}{l}\text { Std. } \\
\text { Deviation }\end{array}$ & $\begin{array}{l}\text { Std. Error } \\
\text { Mean }\end{array}$ \\
\hline Healthy & 35 & 26,40 & 5,637 & 0,953 \\
\hline $\begin{array}{c}\text { Threatened } \\
\text { abortion }\end{array}$ & 36 & 27,03 & 6,245 & 1,041 \\
\hline
\end{tabular}

Table 2

Subdivision of age in two groups

\begin{tabular}{|l|c|c|c|c|}
\hline \multirow{2}{*}{ Groups } & & \multicolumn{2}{|c|}{ Age } & \\
\cline { 2 - 5 } & below $20 \mathrm{yrs}$ & $21-30 \mathrm{yrs}$ & $>31 \mathrm{yrs}$ & Total \\
\hline \multirow{3}{*}{$\begin{array}{l}\text { Healthy women } \\
\mathrm{p} \pm \text { Sp }\end{array}$} & 7 & 21 & 7 & \\
\cline { 2 - 5 } & $20,0 \pm 6,8$ & $60,0 \pm 8,3$ & $20,0 \pm 6,8$ & \multirow{2}{*}{$35100,0 \%$} \\
\hline \multirow{2}{*}{$\begin{array}{l}\text { Threatened abortion } \\
\text { number } \mathrm{p} \pm \text { Sp }\end{array}$} & $25,0 \pm 7,2$ & $44,4 \pm 8,3$ & $30,6 \pm 7,7$ & $100,0 \%$ \\
\hline \multirow{2}{*}{$\begin{array}{l}\text { Total number } \\
\mathrm{p} \pm \text { Sp }\end{array}$} & 16 & 37 & 18 & 71 \\
\cline { 2 - 5 } & $22,5 \pm 5,0$ & $52,1 \pm 5,9$ & $25,4 \pm 5,2$ & $100,0 \%$ \\
\hline
\end{tabular}

Table 3

Obtained results for the evaluated indicators

\begin{tabular}{|c|c|c|c|c|c|c|c|}
\hline Indicators & groups & $\mathbf{N}$ & Mean & Std. Deviation & Std. Error & $\mathbf{u}$ & $\mathbf{P}$ \\
\hline \multirow{3}{*}{ IR.DEX } & Healthy & 35 & 0,79317 & 0,110161 & 0,018621 & \multirow[b]{2}{*}{1.61} & \multirow[b]{2}{*}{$>0.05$} \\
\hline & & & & & & & \\
\hline & $\begin{array}{l}\text { Threatened } \\
\text { abortion }\end{array}$ & 36 & 0,75128 & 0,109488 & 0,018248 & & \\
\hline \multirow{3}{*}{ S.D_DEX } & Healthy & 35 & 5,61257 & 3,114046 & 0,526370 & \multirow[b]{2}{*}{0.65} & \multirow[b]{2}{*}{$>0.05$} \\
\hline & & & & & & & \\
\hline & $\begin{array}{l}\text { Threatened } \\
\text { abortion }\end{array}$ & 36 & 5,08083 & 2,410583 & 0,401764 & & \\
\hline \multirow{3}{*}{ IR.SIN } & Healthy & 35 & 0,78503 & 0,089534 & 0,015134 & \multirow[b]{2}{*}{1.00} & \multirow[b]{2}{*}{$>0.05$} \\
\hline & & & & & & & \\
\hline & $\begin{array}{l}\text { Threatened } \\
\text { abortion }\end{array}$ & 36 & 0,76189 & 0,104281 & 0,017380 & & \\
\hline \multirow{3}{*}{ S.D_SIN } & Healthy & 35 & 5,29657 & 2,641164 & 0,446438 & \multirow[b]{2}{*}{0.93} & \multirow[b]{2}{*}{$>0.05$} \\
\hline & & & & & & & \\
\hline & $\begin{array}{l}\text { Threatened } \\
\text { abortion }\end{array}$ & 36 & 4,80000 & 1,575601 & 0,262600 & & \\
\hline $\mathrm{IR}=\mathrm{IR} \sin -\mathrm{IRdex}$ & Healthy & 35 & 0,05489 & 0,042280 & 0,007147 & 4.37 & $<0,001$ \\
\hline
\end{tabular}




\section{Discussion}

When we compared the two groups, there was a difference concerning the IR $=$ SIN-DEX $\mathrm{P}<0.001$. The controls have smaller averages compared to the experimental group. Probably the difference in blood flow between the left and right uterine artery leading to dissonance in the blood supply to respective sections of the large decidual cells of the superficial layer of the endometrium and consequently, appears to be a difference in the delivery of the progesterone from the corpus luteum. After the first trimester the placenta produces enough estrogen and progesterone and the role of the corpus luteum is ignored. In the first 12 weeks of gestation, the stability of the uterine lining is extremely dependent on progesterone, which is secreted by the corpus luteum. If one part of the endometrial cells does not receive adequate amounts of estrogen, progesterone and growth factors, which require good blood supply, those layers of the decidual lining begin to drop, and it bleeds ex utero. Similar processes lead to the menstrual bleeding of the endometrial cycle, but there is a total exfoliation of the endometrium because of the complete atrophy of the corpus luteum, and a total cessation of its hormonal secretion.

All vessels that provide blood flow to the uterus have extensive anastomoses with each other, causing even violations in the bloodstream of the uterine artery and may not drastically respect the outcome of the pregnancy. Establishing a difference in the blood supply would rather orient us concerning which women would expect complications such as bleeding and pain, but it enables us to forecast the outcome of pregnancy. These women may be advised to reduce physical stress, and if their work requires it to be reassigned from the beginning of the pregnancy. The increased physical activity is responsible for the redistribution of a large part of the circulation to the lower extremities, which will lead to an even greater deterioration in the uterine blood flow.

There is no correlation between the difference in the blood flow to the left and right uterine artery and the interruption of pregnancy. From the very beginning of the pregnancy, one of the most notable changes in the uterus that occurs is constant and progressive increase in blood flow. Depending on the location of the trophoblastic reaction a possible increase in the blood flow in one uterine artery occurs before the improving of the perfusion of the contralateral. The results are similar from the conducted four studies of uterine artery blood flow in women with threatened miscarriage. The authors concluded that Doppler arteria uterina is not beneficial positive predictor of differrentiation concerning which case of the threatened abortion will end with the termination of pregnancy before 20 GS [9-11]. The results obtainned do not match those obtained by Manal and colleagues at the University Hospital in Zagazig [12]. One should not ignore the fact that they use the combined study of human chorionic gonadotropin and Doppler velocimetry of the left and right uterine artery. The Doppler study of the uterine artery improves the specificity and sensitivity of the prognostic value of the dynamics in the levels of human chorionic gonadotrophin on the outcome of early pregnancy. There was not shown a significant correlation with statistical processing of the results of the increased difference in the index of resistance and the ratio S / D in pregnant women diagnosed with threatened abortion compared to the control group.

\section{Conclusion}

Apparently the Doppler study is not convenient to independently distinguish risk groups for pregnant miscarriage of normal ongoing pregnancies, but it would be useful as an additional study.

\section{REFERENCES}

1. Schorge J, Halvorson L, Schaffer J. et al. First-Trimester Abortion, Williams Gynecology. 2008, Ch. 6

2. Wilcox AJ, Weinberg CR, O'Connor JF et al. Incidence of early loss of pregnancy. N Engl J Med. 1988; 319: 189-194.

3. Hollis B, Mavrides E, Campbell S, Tekai A, Thilaganathan B. Reproducibility and repeatability of transabdominal uterine artery. Doppler velocimetry between 10 and 14 weeks of gestation. Ultrasound Obstet Gynecol. 2001; 18: 593-7.

4. Ivanov P Gecheva St., Tsvyatkovska Tsv.i satr.677 C> $\mathrm{T}$ polymorphism in the MTHFR as a factor for embryonic losses ploda.Akusherstvo and ginekologiya. 2014 ; 53(1): 8-12.

5. Urato A, Norwitz ER, A guide towards pre-pregnancy management of defective implantation and placentation, Best Practice \& Research Clinical Obstetrics and Gynaecology. 2011; 25: 367-387.

6. Hoozemans DA, Schats R, Lambalk CB, et al. Human embryo implantation: current knowledge and clinical implications in assisted reproductive technology. Reprod BioMed Online. 2004; 9: 692-715. 
7. Jauniaux E. Design, beauty and differentiation: the human fetus during the first trimester of gestation. Reprod BioMed, Online. 2000; 1: 107-108.

8. Norwitz ER, Schust DJ \& Fisher SJ. Implantation and the survival of early pregnancy. N Engl J Med. 2001; 345: 1400-1408.

9. Alkazar JL, Ruiz-Perez ML. Uteroplacental circulation in patients with first trimester threatened abortion. Fertil Steril. 2000; 73: 130-5.

10. Kurjak A, Zudenigo I, Predanic M, Kupesic S, Funduk B. Assessment of the fetomaternal circulation in threatened abortion by transvaginal color Doppler. Fetal Diag Ther. 1994; 9: 341-7.

11. Pellizzari P, Pozzan C, Marchiori S, Zen T, Gangemi M. Assessment of uterine artery blood flow in normal first-trimester pregnancies and in those complicated by uterine bleeding. Ultrasound Obstet Gynecol. 2002; 19: 366-70.

12. Manal M, et al. Uterine artery Doppler and urinary hyperglycosylated $\mathrm{HCG}$ as predictors of threatened abortion outcome, Middle East Fertility Society Journal (2013) from 18.42 to 46.

Резиме

\section{ДОПЛЕР ВЕЛОСИМЕТРИЈА}

НА АРТЕРИИТЕ НА МАТКАТА: ТЕСТ НА РАН СКРИНИНГ ЗА СПОНТАН АБОРТУС

\section{Илијан Трајанов, Елена Димитракова}

УМБАЛ Св. Ѓорѓи - Пловдив,

Оддел за акушерство и гинекологија,

Катедра за акушерство и гинекологија, Р. Бугарија

Boвeg: Според C3О, спонтаниот абортус е дефиниран како „губење на бременоста пред возраста од 20 недели од бременоста или тежи- на на фетусот под 500 g“. Само 50-60\% од сите зачнувања не успеваат да преживеат 20 недели од бременоста. Се проценува дека околу $75 \%$ од сите неуспешни зачнувања се должат на неуспешната имплантација и не се пријавени како спонтани абортуси.

Майеријал и мейоgи: Извршивме проспективна опсервациска студија на Одделот за акушерство и гинекологија на Медицинскиот универзитет во Пловдив меѓу октомври 2014 и септември 2015 година. Проучувавме две групи бремени жени: жени со ризик за абортус и оние со нормална бременост. Сите жени беа подложени на трансвагинална евалуација со ултразвук на протокот на артериската крв на матката. Ја меревме најголемата систолна и крајната дијастолна брзина и го пресметувавме просечниот IR (индекс на отпор) и S/D (однос систолен и дијастолен).

Резулйайи: Не постоеше поврзаност помеѓу исходот на бременоста и средната разлика помеѓу артерискиот IR на матката и $\mathrm{S} /(\mathrm{P}>0,05)$.

Заклучок: Во нашата студија, со доплер ултразвукот не може да се направи разлика помеѓу жените со ризик за спонтан абортус и нормалните жени. Понатамошни студии се потребни за да се одговори на ова прашање.

Клучни зборови: Доплер ултразвук, индекс на отпор, бременост, ризик од абортус 
